\title{
KESIAPAN PENERAPAN PROTOKOL KESEHATAN DI LINGKUNGAN SEKOLAH DASAR PANGUDI LUHUR JAKARTA SELATAN
}

\author{
1Teguh Supono. ${ }^{2}$ Witarsa Tambunan \\ 1,2 Mahasiswa Magister Administrasi Pendidikan PPs-UKI, Jakarta, Indonesia, ${ }^{2}$ Dosen Magister \\ Administrasi Pendidikan PPs -UKI, Jakarta Indonesia \\ e-mail: witarsa.oke@gmail.com
}

\begin{abstract}
The impact of the COVID-19 pandemic the government makes policies in the learning process, from face-to-face learning to online learning. Over time, it turned out that online learning could not run optimally due to several things, including socialization and preparation which were not ready in terms of planning, implementation to evaluation, including readiness for online learning methods. Based on this problem, the Minister of Education and Culture Nadiem Makarim instructed that all schools should have opened face-to-face learning by July 2021. The decision taken by Nadiem Makarim is based on a Joint Decree of 4 Ministers which provides rules regarding face-to-face schools. Pangudi Luhur Elementary School already has rules for implementing the Health Protocol in the form of a Decree from the Principal/ Foundation. The purpose of this study was to determine the level of readiness of the school community in implementing health protocols in the school environment as an effort to prevent the spread of COVID19, as a basis for consideration in welcoming face-to-face schools. The research method was descriptive qualitative with in-depth interviews. The results of the study show that the level of readiness of the Pangudi Luhur Elementary School South Jakarta Community, for the implementation of the COVID-19 health protocol is quite high, but continuous education and socialization is still needed, so that it can have a positive impact on face-to-face learning plans.
\end{abstract}

Keywords: school community readiness, social distancing, online learning

\begin{abstract}
Abstrak
Dampak pandemic COVID-19 pemerintah membuat kebijakan dalam proses pembelajaran, dari pembejaran tatap muka menjadi pembelajaran dalam jaringan (daring). Dalam berjalannya waktu, ternyata pembelajaran daring tidak bisa berjalan dengan maksimal disebabkan beberapa hal, diantaranya adalah sosialisasi dan persiapan yang belum siap dari segi perencanaan, pelaksanaan hingga evaluasi termasuk kesiapan tentang metode pembelajaran daring. Berdasarkan masalah tersebut, maka Mendikbud Nadiem Makarim menengintrusikan bahwa semua sekolah harus sudah membuka belajar tatap muka pada Juli 2021. Keputusan yang diambil oleh Nadiem Makarim berdasarkan keputusan SKB 4 Menteri yang memberi rambu-rambu tentang sekolah tatap muka. Sekolah Dasar Pangudi Luhir telah memiliki aturan penerapan Protokol Kesehatan berupa Surat Keputusan Kepala sekolah/Yayasan. Tujuan dari penelitian ini adalah untuk mengetahui tingkat kesiapan warga sekolah dalam penerapan protokol kesehatan di lingkungan sekolah sebagai upaya pencegahan penyebaran COVID-19, sebagai dasar pertimbangan menyambut sekolah tatap
\end{abstract}


muka. Metode penelitian ini adalah kualitatif deskriptif dengan wawancara mendalam. Dari hasil penelitian menunjukkan bahwa tingkat kesiapan warga Sekolah Dasar Pangudi Luhur Jakarta selatan, terhadap penerapan protokol kesehataan COVID-19 cukup tinggi, tetapi tetap diperlukan edukasi dan sosialisasi terus menerus, sehingga dapat berdampak positif terhadap rencana pembelajaran tatap muka.

Kata Kunci: kesiapan masyarakat sekolah, social distancing, pembelajaran daring

Citation: Supono, T., \& Tambunan, W. (2021). KESIAPAN PENERAPAN PROTOKOL KESEHATAN DI LINGKUNGAN SEKOLAH DASAR PANGUDI LUHUR JAKARTA SELATAN. Jurnal Manajemen Pendidikan, 10(2), 57-65. Retrieved from http://ejournal.uki.ac.id/index.php/imp/article/view/3269

\section{PENDAHULUAN}

Pemerintah melalui Mendikbud Nadiem Makarim menegaskan bahwa semua sekolah harus sudah membuka belajar tatap muka pada Juli 2021. Keputusan yang diambil oleh Nadiem Makarim berdasaarkan keputusan SKB 4 Menteri yang memberi rambu-rambu tentang sekolah tatap muka(Syindi Oktaviani R. Tolinggi, Febry Ramadani 2020:8). Rencana Pemerintah untuk membuka kembali sekolah tatap muka ternyata menimbulkan pro dan kontra di kalangan masyarakat luas. (Yudi Umara, Mar'atun Hasanah 2020:4) Bagi kalangan masyarakat yang pro terhadap sekolah tatap muka, maka berita ini adalah suatu kabar baik bagi dunia pendidikan Indonesia, karena selama ini model pembelajaran jarak jauh dianggap kurang maksimal, sehingga berpengaruh negative terhadap motivasi dan prestasi siswa. Sedangkan bagi masyarakat yang kurang setuju dengan belajar tatap muka, melihat bahwa keputusan tersebut dinilai terlalu berani dan bisa membahayakan keselamatan tenaga pendidik dan kependidikan ataupun peserta didk, mengingat kasus penularan COVID-19 belum terkendali dengan baik. Pelaksanaan pembelajaran tatap muka bisa mulai diadakan dengan syarat wajib mentaaati protocol kesehatan secara ketat (Ibnu Darmawan 2020 :193)

Keresaahan dan keraguan masyarakat terhadap rencana tatap muka disebabkan masih tingginnya kasus COVID-19 yang terjadi di Indonesi, sehingga masyarakat kawatir jika sekolah tatap muka dipaksakan dapat menimbulkan terjadinya kalster baru pada dunia pendidkan/sekolah (Ahmad Fikri Sabiq 2020:181). Niat baik pemerintah untuk mengadakan sekolah tatap muka mendapat sambutan yang beragam dari masyarakat, dan bisa berpotensi menimbulkan kegaduhan dan membuang energi positip, serta dapat mengaburkan makna dan tujuan dan niat baik pemerintah untuk menyelamatkan dunia pendidikan. Menurut peneliti sumber dari pro dan kontra yang berkepanjangan karena pembuat kebijakan dalam hal ini pemerintah tidak mengidentifikasi dahulu pokok permasalahan dari rencana tatap muka yang akan diterapkan mekipun pandemic COVID-19 belum sepenuhnya dapat dikendalaikan. Menurut penulis, pokok masalah dari isu rencana sekolah tatap muka adalah .Rendahnya penggunaan PROKES di Lingkungan Sekolah.

Secara umum, protokol dapat dipahami sebagai suatu pedoman berisi tentang tata cara kegiatan, dan semua hal yang mengatur pelaksanaan kegiatan (Arista Aulia F, dkk 2021:113) Sedangkan I Putu Suarsana Ariesta (2021:21) menjelaskan bahwa protokol adalah serangkaian peraturan yang dikeluarkan negara, yang berlaku dan harus ditaati oleh semua warga negara demi menjaga stabilitas berbagai aspek kehidupan. Berdasarkan pendapat di atas, dapat disimpulkan bahawa protokol kesehatan merupakan suaatu panduan yang berisi aturan-aturan tentang perilaku hidup bersih dan sehat dalam rangka menjaga kesehatan tubuh agar terbebas dari penularan suatu penyakit, dalam konteks ini, terbebas dari penularan COVID-19. Gennaro dalam Arnas dkk 
(2020:88) menegaskan bahwa protokol kesehatan merupakan salah satu cara yang perlu diterapkan untuk mencegah penyebaran kasus infeksi COVID-19. Protokol kesehatan secara umum harus memuat Perlindungan Kesehatan Individu Penularan Covid-19 terjadi melalui droplet yang dapat menginfeksi manusia dengan masuknya droplet yang mengandung virus SARS-CoV-2 ke dalam tubuh melalui hidung, mulut, dan mata (Ronaldo dkk 2021:8).

Penerapan protokol kesehatan perlu untuk terus ditingkatkan, mengingat sampai saat ini penyebaran COVID-19 masih relative tinggi. Data menunjukan hingga Sabtu 22/5/2021 pukul 12.00 WIB, kasus positif Covid-19 di Indonesia bertambah sebanyak 5.296 (KOMPAS. com, 2021) Hal tersebut menunjukan, bahwa penemuan antivirus dan vaksinasi yang telah dilaksnakan oleh pihak pemerintah kepada sebagian warga belum dapat menekan penyebaran COVID-19. Oleh kerena itu diperlukan budaya atau gaya hidup baru yang sehat, diantaranya adalah tetap optimis, olahraga teratur/melakukan aktifitas fisik, konsumsi gizi seimbang, menjaga jarak, mencuci tangan, dan menerapkan pola hidup bersih lainnya secara berkelanjutan (Taufiq Firdaus Al-Ghifari Atmadja, dkk 2020:201).

Penerapan protokol kesehataan merupakan bagaian penting yang tidak dapat diabaikan dalam rangka mengurangi penyebaran COVID-19. Hal ini sesuai dengan Instruksi Presiden Republik Indonesia nomor 6 tahun 2020 Tentang Peningkatan Disiplin dan Penegakan Hukum Protokol Kesehatan Dalam Pencegahan dan Pengendalian Covid-19. Intruksi Presiden ditujukan dianataranya kepada segenap aparat pemerintah untuk bersama-sama dengan tokoh agama, tokoh masyarakat, dan tokoh adat untuk meningkatkan dan penegakan hukum protokol kesehatan dala pencegahan dan pengendalian COVID-19.

Masih terkait dengan protokol kesehatan, salah satu pasal dalam instruksi Presiden menegaskan tentang perlunya gubernur, bupati atau wali kota mnyusun dan menerbitkan suatu peraturan yang memuat ketentuan mematuhi protokol kesehatan yang wajib dilaksanakan oleh perorangan, pelaku usaha, pengelola, peyelenggara pendidikan, dan penanggung jawab fasilitas-fasulitas umum. Berdasarkan instruksi Presiden tersebut, maka dinas pendidikan/ Yayasan sebagai peneyelengara pendidikan harus mempu memberikan penyadaran kepada semua warga sekolah akan perlunya penerepan protokol kesehatan, terutama di lingkungan sekolah, dengan demikian akan tercipta lingkungan sekolah aman, dan terbebas dari penyebaran COVID-19. Selain itu, kriteria lingkungan sekolah yang aman dari penyebaran COVID-19 juga sudah ditentukan dalam Surat Keputusan Bersama Empat Kementerian(Menteri Pendidikan dan Kebudayaan, Menteri Agama, Menteri Keehatan dan Menteri dalam Negeri ) tentang Panduan Penyelenggaraan Pembelajaran pada Tahun Ajaran dan Tahun Akademik Baru di Masa Pandemi Covid-19. Adapun beberapa syarat atau protokol yang harus dipenuhi oleh sekolah terkait keputusan keputusan empat Menteri di atas adalah 1) sarana dan prasarana memadai, baik dari segi fungsi maupun kebersihanya, misalnya toilet dan tempat cuci tangan dalam keadaan bersih dan siap pakai, selalu tersedia sabun atau cairan pembersih tanggan; 2)mampu mengakses fasilitas dan layanan kesehatan (puskesmas, klinik, rumah sakit dan lainnya); 3) kesiapan menerapkan area wajib masker kain atau masker tembus pandang bagi yang memiliki peserta disabilitas rungu; 4) memiliki thermogun(pengukur suhu tubuh tembak); 5) pemetaan warga satuan pendidikan yang tidak boleh melakukan kegiatan dari satuan pendidikan, seperti: memiliki kondisi medis penyerta. (Nofrita 2020:185).

Kepala sekolah dan guru adalah teladan, model dan motor penggrak dalam menjalankan protokol kesehatan di lingkungan sekolah. Mereka harus menjadi orang pertama dan terdepan dalam mengkampanyekan protokol kesehatan sesuai himbauan pemerintah, hal ini penting untuk dilakukan, karena jika tidak maka sekolah dapat berpotensi menjadi klaster baru penyebaran COVID-19. Selain itu, sekolah juga harus memastikan fasilitas memadai. Persiapan dan penerapan protokol kesehatan di lingkungan sekolah secara massif akan dapat mencegah peserta didik dari tertularnya COVID-19, selain itu juga dapat memberikan ketengan batin untuk orang tua peserta didik dan seluruh warga sekolah (Jejen M 2020:131) 


\section{METODE PENELITIAN}

Penelitian ini menggunakan metode kualitatif. Metode kualitatif bisa dipahami sebagai prosedur riset yang memanfaatkan data deskriptif, berupa kata-kata tertulis atau lisan dari orang-orang dan pelaku yang dapat diamati. Penelitian kualitatif dilakukan untuk menjelaskan dan menganalisis fenomena, peristiwa, dinamika sosial, sikap kepercayaan, dan persepsi seseorang atau kelompok terhadap sesuatu. Maka, proses penelitian kualitatif dimulai dengan menyusun asumsi dasar dan aturan berpikir yang akan digunakan dalam penelitian. Data yang dikumpulkan dalam riset ini kemudian ditafsirkan. Dalam penelitian ini, penulis menggunakan pendekatan wawancara dan observasi lapangan untuk mendapatkan data penelitian.

\section{HASIL DAN PEMBAHASAN}

Rendahnya penggunaan protokol kesehatan di lingkungan sekolah

Protokol kesehatan adalah suatu aturan dan ketentuan yang perlu ditaati oleh segala pihak agar dapat beraktivitas secara aman pada saat pandemi COVID-19 ini. Tujuan dari protokol kesehatan antara lain agar masyarakat tetap dapat beraktivitas secara aman dan tidak membahayakan keamanan atau kesehatan orang lain. Protokol Kesehatan menurut Menteri Kesehatan Republik Indonesia secara umum harus memuat Perlindungan Kesehatan Individu Penularan Covid-19 terjadi melalui droplet yang dapat menginfeksi manusia dengan masuknya droplet yang mengandung virus SARS-CoV-2 ke dalam tubuh melalui hidung, mulut, dan mata(Ronaldo dkk 2021:8). Keresahan masyarakat terhadap rancana sekolah tatap muka disebabkan oleh ketidakyakinannya terhadap kemampuan dan konsistensi pihak sekolah di dalam menyiapkan protokol kesehatan yang dibutuhkan oleh pendidik dan peserta didik, sehingga tidak tertular COVID-19. Adapun protokol kesehatan yang perlu dipersiapkan disekolah, yakni ;

a. Ketersediaan sarana sanitasi dan kebersihan, seperti: toilet bersih, sarana cuci tangan/wastavel dengan air mengalir menggunakan sabun atau cairan pembersih tangan (hand sanitizer) dan disinfektan;

b. Mampu mengakses fasilitas dan layanan kesehatan terdekat seperti puskesmas, klinik, rumah sakit;

c. Kesiapan menerapkan area wajib menggunakan masker;

d. Memiliki thermogun(pengukur suhu tubuh tembak);

e. Pemetaan warga satuan pendidikan yang tidak boleh melakukan kegiatan dari satuan pendidikan, seperti: memiliki kondisi medis penyerta (comordity) yang tak terkontrol, tidak memiliki akses transportasi yang memungkinkan penerapan jaga jarak, memiliki riwayat perjalanan dari zona kuning, orange danmerah atau riwayat kontak dengan orang terkonfirmasi positif Covid-19 dan belum menyelesaikan isolasi mandiri selama 14 hari;

f. Menyiapkan ruangan kelas sesuai dengan protokol kesehatan;

g. Menyiapkan jalur lalulintas pejalan kaki di lingkungan sekolah agar tidak menimbulkan kerumunan/jaga jarak (Nofrita dkk 2020:185, Krista L. Pattison 2021:382) 


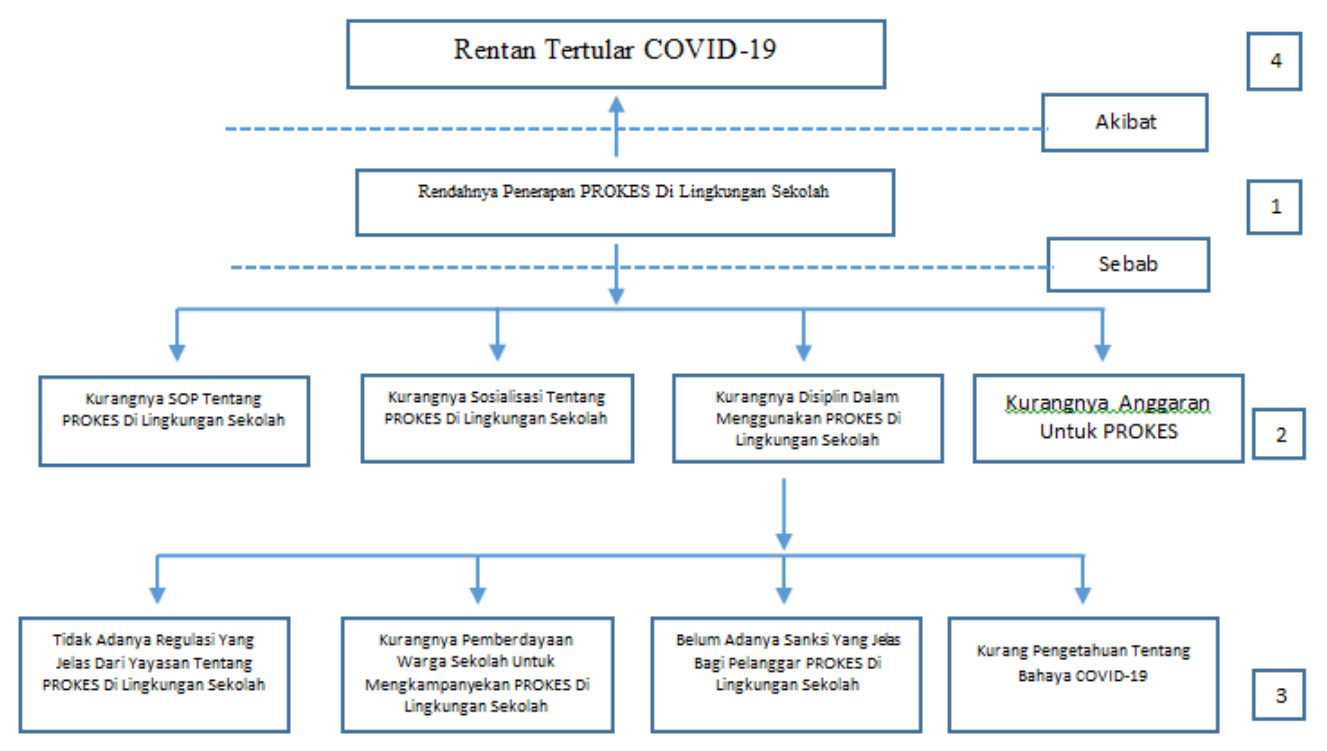

Gambar 1

Pohon Masalah

Beberapa hal yang menyebabkan rendahnya penggunaan protokol kesehatan di lingkungan sekolah Kurangnya SOP tentang PROKES di Lingkungan Sekolah

Tingkat kesadaran masyarakat dalam menggunakan atau mentaati protokol kesehatan pada umumnya masih rendah. Banyak yang mengabaikan protokol kesehatan dengan alasan atau dalih yang bermacam-macam, salah satu alasanya adalah tidak ada SOP yang mengatur penggunaan dan mentaati protokol kesehatan, terutama di lingkungan sekolah. Penyusunan SOP dalam rangka penyegahan COVID-19 mutlak untuk dilakukan, demi keselamatan pelanggan, dalam hal ini demi keselamatan peserta didik, pendidik, dan warga sekolah pada umumnya. Hal ini juga sesuai dengan Undang Undang Nomor 30 Tahun 2014 tentang Administrasi Pemerintahan bagian kelima pasal 49 ayat 1,2 dan 3 mewajibkan penyusunan SOP dan mengumumkannya kepada public (Cepi Safrul Alam 2020:59)

Kurangnya sosialisasi tentang PROKES di Lingkungan Sekolah

Sejak awal terjadinya wabah pandemic COVID-19, dinas pendidikan sudah mengintruksikan pihak sekolah bersama dengan komite sekolah untuk meyusun dan mensosialisasikan protokol kesehatan terkait COVID-19 yang ada di wilayahnya, dengan tujuan agar semua warga sekolah mendapatkan edukasi yang tepat dan bisa mencegah penyebaran dan penularan COVID-19. Tetapi pada kenyataannya masih banyak sekolah yang tidak mengindahkan himbauan tersebut, sehingga masih banyak dijumpai para pendidik maupun orang-orang disekitar sekolah yang kebetulan melaksanakan piket tidak menggunakan atau mengabaikan protokol kesehatan. Oleh karena itu, kegiatan sosialisasi sangat penting di lakukan sehingga seseorang memiliki pemahaman yang benar tentang penyebaran COVID-19 (Emusti Rivashintha Marjito, dkk 2020:93).

Kurangnya anggaran untuk PROKES di Lingkungan Sekolah

Salah satu masalah dalam pelaksanaan dan pengadaan protokol kesehatan adalah terbatasnya anggran yang disediakan, terlebih wabah COVID-19 adalah suatu bencana yang tidak terduga, sehingga banyak instansi atau lembaga tidak menyiapkan anggaran secara khusus untuk penanganan kasus COVID 19. Untuk di sekolah, kepala sekolah sebagai pemimpin sekolah mempeunyi keleluasaan untuk mengelola dana BOS secara lebih lues, termasuk untuk penanggulangan COVID-19. Hal ini sesuai dengan Peraturan Kemendikbud Nomor 19 Tahun 2020

Teguh Supono. Witarsa Tambunan PENERAPAN PROTOKOL KESEHATAN DI LINGKUNGAN SEKOLAH DASAR PANGUDI LUHUR JAKARTA SELATAN| 61 
dan Surat Edaran Kemenag nomor B-699/ Dt.l.l/PP.03/03/2020 mengizinkan penggunaan dana BOS untuk pelaksanaan pembelajaran jarak jauh (Nadia Fairuza Azzahra 2020:4).

Kurangnya disiplin dalam menggunakan PROKES

Ada beberapa penyebab sehingga seseorang abai atau tidak disilpin serta kurang mengindahkan protokol kesehatan, yaitu;

a. Adanya persepsi hambatan (percieved barriers), yaitu kesulitan memahami informasi yang diberikan pemerintah sehinngga menyebabkan kesulitan mengakses informasi karena peralatan komunikasi yang tidak memadai, lebih mengutamakan kebutuhan lainnya misalnya ekonomi, serta ketidakpercayaan terhadap kebijakan dan pernyataan pemerintah yang dianggap kurang konsisten;

b. Persepsi manfaat (per-cieved benefit), kebiasaan berkumpul dan merasa penerapan 3M tidak berguna dan dianggap sebagai sesuatu yang berlebihan(sia-sia) seiring keluarnya istilah new normal dan adanya pelonggaran PSBB;

c. Persepsi kerentanan (perceived susceptibility), usia di bawah 50 tahun dipersepsikan masih memiliki kondisi tubuh yang masih kuat dan imunitas yang baik sehingga tidak mudah terpapar virus; 4) persepsi keparahan (percei-ved severity), beberapa masyarakat meyakini jika terpapar virus tidak akan parah dan tingkat kesembuhan akan lebih cepat; 5) petunjuk bertindak (cues to action),tidak ada figure atau tokoh yang dapat dijadikan sebagai panutan atau contoh dalam melakukan atau melaksanakan protokol kesehatan (Ratna Kartika Sari 2021:93)

Selain beberapa hal di atas, kurangnya disiplin dalam menggunakan prokes juga dapat disebabkan oleh hal-hal sberikut ini;

a. Tidak adanya regulasi yang jelas dari Yayasan tentang PROKES di lingkungan sekolah. Regulasi apapun bentuknya sangat dibutuhkan sebagai payung hukum dalam membuat atau melakukan sesuatu, dalam hal ini regulasi dibutuhkan sebagai dasar pembuatan protokol kesehatan untuk lingkungan sekolah.

b. Kurangnya pemberdayaan warga sekolah untuk mengkampanyekan PROKES di Lingkungan. Sekolah tidak bisa kekerja sendirian dalam mengatasi permasalahan, termasuk ketika akan mengadakan gerakan atau mengkampanyekan sesuatu yang penting, misalnya gerakan anti bebas COVID-19. Sekolah perlu melibatkan pihak-pihak lain yang memiliki kepedulian terhadap kesehatan.

c. Belum adanya sanksi yang jelas bagi pelanggar PROKES di lingkungan sekolah. Demi terlaksananya program protokol kesehatan di lingkungan sekolah, sekolah bisa membuat sanksi yang jelas dan tegas bagi pelanggar protokol kesehatan di lingkungan kesehatan.

d. Kurang pengetahuan tentang bahaya COVID-19. Rendahnya pengetahuan dan pemahaman terhadap bahaya COVID-19, bisa menyebabkan individu atau seseorang bertindak fatal, sehingga dapat merugikan diri sendiri dan orang lain. 


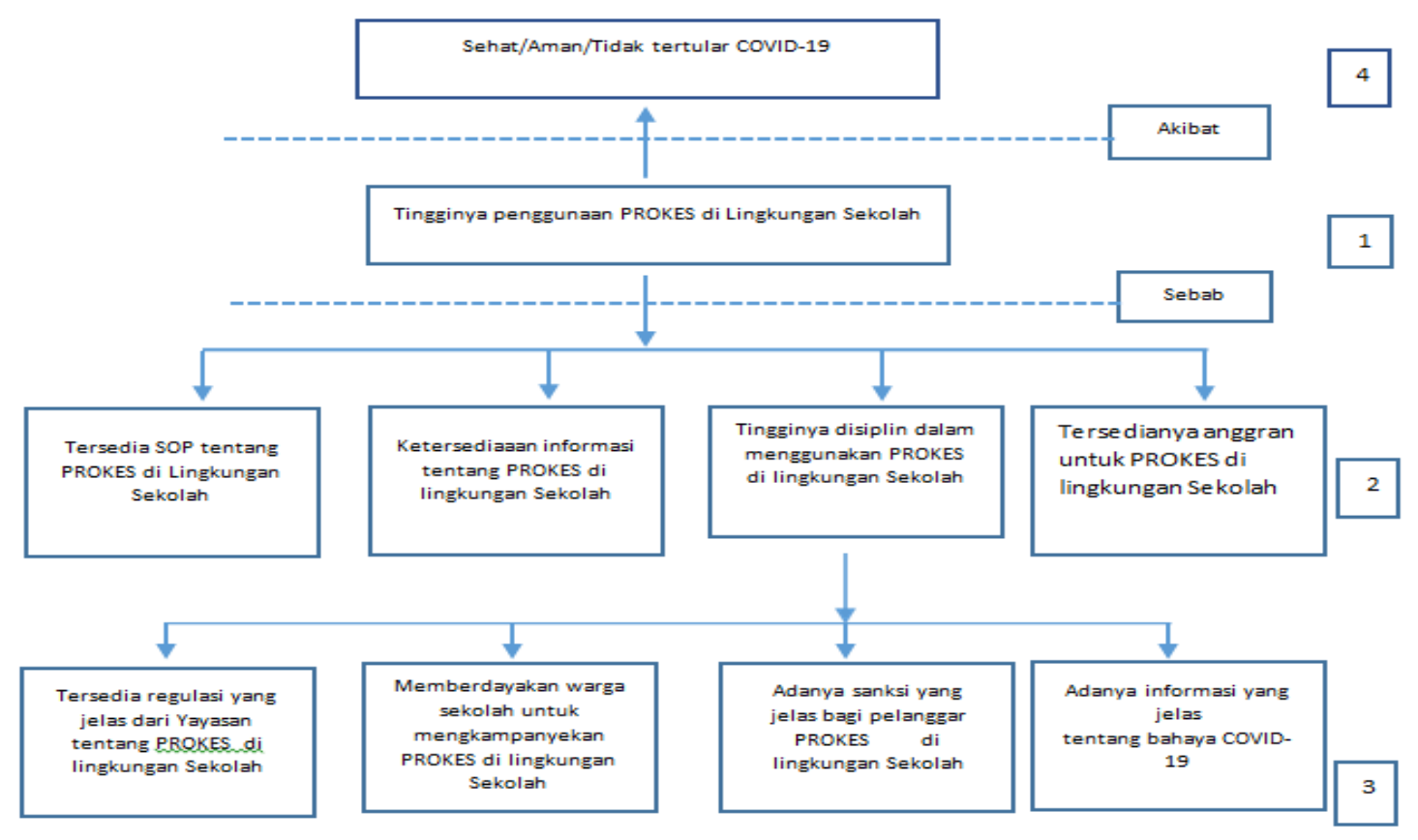

Gambar 2.Pohon Sasaran

Untuk meningkatkan penggunaan protokol kesehatan di lingkungan sekolah, sekolah memberdayakan nunsusr-unsur yang ada di lingkungan sekolah, salah satunya adalah warga sekolah. Ada beberapa hal agar pemberdayaaan warga sekolah untuk mengkampanyekan PROKES di lingkungan sekolah dapat berjalan sesuai dengan maksudnya;

a. Tersedia regulasi yang jelas dari Yayasan/lembaga tentang PROKES di lingkungan Sekolah. Sebelum mengumpulkan dan menggerakan warga sekolah sebagai relawan untuk menkampanyekan COVID-19, sekolah perlu menyiapkann regulasi yang jelas sebagai dasar sebagai dasar untuk berbuat dan melangkah;

b. Pelatihan SDM SATGAS COVID-19 di lingkungan Sekolah. Perlu adanya pelatihan dan pengembangan untuk SDM KOVID-19 yang telah dibentuk dan disahkan oleh sekolah, dengan tujuan dapat menjalan tugasnya secara lebih baik;

c. Menggunakan MEDSOS untuk menkampanyekan PROKES di Lingkungan Sekolah. Sekolah bisa memanfaatkan teknologi informasi dengan segala fitur-fiturnnya untuk menngkampanyekan pentingnya protokol kesehatan di lingkungan sekolah;

d. Menyediakan anggaran untuk PROKES di Lingkungan Sekolah;

e. Bekerja sama dengan Komite Sekolah dan Puskesmas setempat. Sekolah bisa menggandeng komite sekolah beserta lembaga -lembaga terkait misalnya Puskesmas yang ada di lingkungan sekolah. 


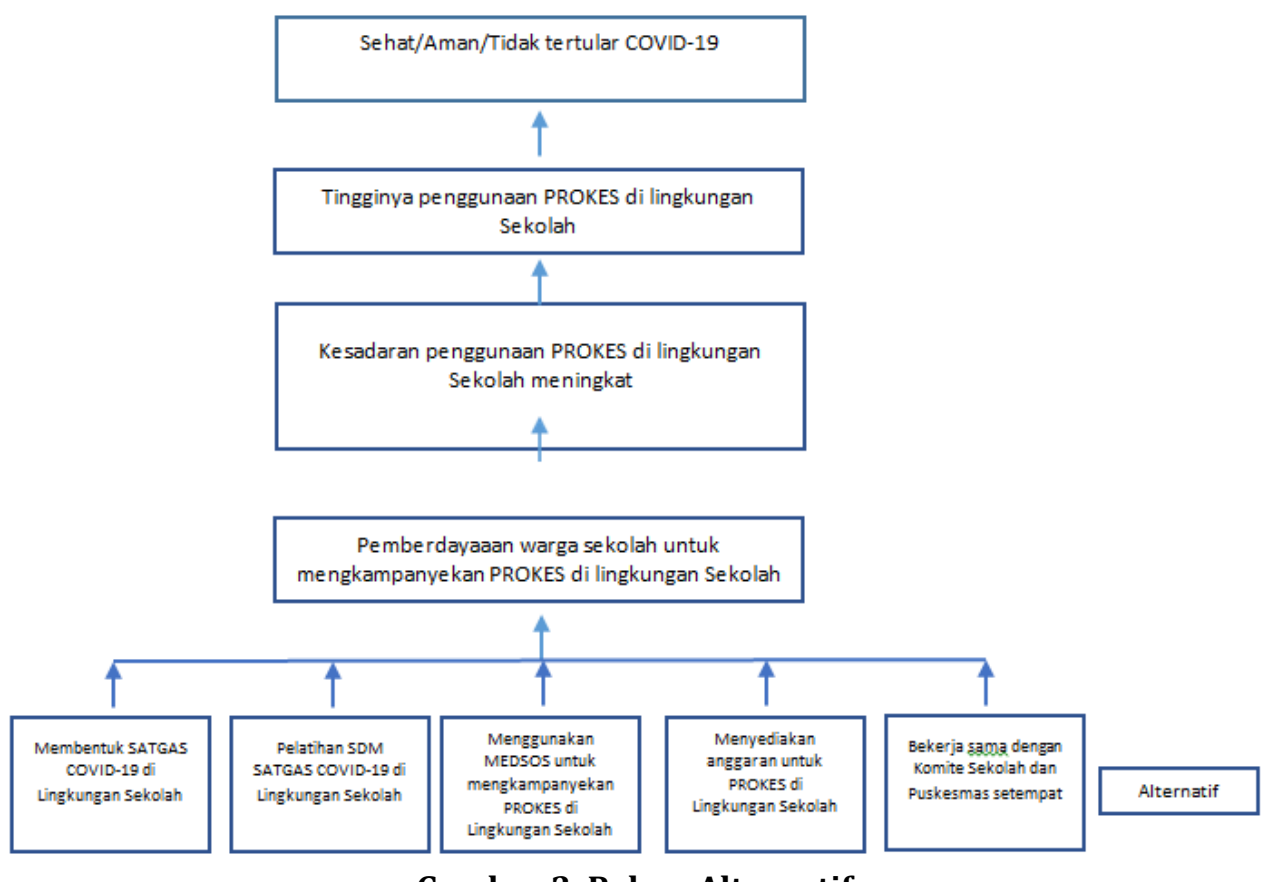

Gambar 3. Pohon Alternatif

\section{KESIMPULAN}

Kesimpulan

Rencana pemerintah untuk mengadakan belajar tatap muka sangat depengaruhi oleh kesuksesan dan kepedulian masyarakat dalam menekan penyebaran COVID-19. Oleh karena itu, pihak sekolah perlu untuk terus mengedukasi dan mengajak seluruh warga sekolah untuk menjadi pelopor dalam penerapan protokol kesehatan di lingkungan sekolah. Tingginya kesadaran warga sekolah terhadap penggunaan protokol kesehatan di lingkungan sekolah akan berdampak positif pada penerapan protokol kesehatan di likungan sekolah, sehingga dapat menekan pemyebaran COVID-19 di lingkungan sekolah. Dengann demikian, lingkungan sekolah menjadi tempat yang aman bagi warga sekolah untuk melakukan kegiatan belajar.

Impilkasi

Adapun implikasi bagi sekolah terkait rendahnya penggunaan protokol kesehatan di lingkungan sekolah adalah; 1) pihak sekolah membuat regulasi terkait dengan penerapan protokol kesehatan di lingkungan sekolah; 2) pihak sekolah menyediakan sarana prasarana terkait protokol kesehatan di lingkungan sekolah; 3) pihak sekolah terus-menerus melakukan sosialisasi atau mengkampanyekan pentingnya protokol kesehatan di lingkungan sekolah kepada seluruh warga sekolah.

Saran

Melihat pentingnya pencegahan penyebaran COVID-19 di lingkungan sekolah, pihak sekolah bisa memberdayakan seluruh warga sekolah untuk terlibat aktif dalam mengkampanyekan pentingnya protokol kesehatan. Oleh karena itu sekolah perlu melakukan langkah-langkah sebagai berikut yaitu; 1)pelatihan SDM SATGAS COVID-19 di lingkungan Sekolah; 2) menggunakan MEDSOS untuk menkampanyekan PROKES di Lingkungan Sekolah; 3) menyediakan anggaran untuk PROKES di Lingkungan Sekolah; 4) bekerja sama dengan Komite Sekolah dan Puskesmas setempat. 


\section{DAFTAR PUSTAKA}

1. Alam, C. S. Pentingnya Penyusunan Standar Pelayanan di Masa Pandemi Covid 19.

2. Atmadja, T. F. A., Yunianto, A. E., Yuliantini, E., Haya, M., Faridi, A., \& Suryana, S. (2020). Gambaran sikap dan gaya hidup sehat masyarakat Indonesia selama pandemi Covid19. AcTion: Aceh Nutrition Journal, 5(2), 195-202.

3. Azzahra, N. F. (2020). Mengkaji Hambatan Pembelajaran Jarak Jauh di Indonesia di Masa Pandemi Covid-19.

4. Darmawan, I. (2020, December). PEMBELAJARAN PENDIDIKAN JASMANI SECARA TATAP MUKA DI ERA NEW NORMAL. In Seminar \& Conference Nasional Keolahragaan (Vol. 1).

5. Di Era Adaptasi Kebiasaan Baru, A. K. B. Optimalisasi Pembelajaran Bahasa Arab.

6. Firdaus, A.A. (2021) Dampak COVID-19 Terhadap Kebijakan Pendidikan di Indonesia, antara Idealisme dan Realitas. UAD PRESS

7. Ita, N., Anita, I., Hermawan, L., \& Junaedi, D. (2020). Pemberdayaan Sekolah Merdeka Melalui Optimalisasi Penerapan Protokol Kesehatan dalam Upaya Sekolah Bebas Covid-19.Jurnal Pengabdian Tri Bhakti, 183-190.

8. Marjito, E. R., Kusnoto, Y., Suwarni, S., \& Hidayat, S. (2021, March). SOSIALISASI PROTOKOL KESEHATAN MASA PANDEMI COVID 19 DI MADRASAH ALIYAH AL-IKHLAS KUALA MANDOR B KABUPATEN KUBU RAYA. In PROSIDING SEMINAR NASIONAL PENELITIAN DAN PENGABDIAN KEPADA MASYARAKAT (SNPP) (Vol. 1, No. 1, pp. 89-94).

9. Musfah, J. (2020). KEPEMIMPINAN KEPALA SEKOLAH ERA PANDEMI. In Seminar Nasional Arah Manajemen Sekolah Pada Masa Dan Pasca Pandemi Covid-19.

10. Pattison, K. L., Hoke, A. M., Schaefer, E. W., Alter, J., \& Sekhar, D. L. (2021). National Survey of School Employees: COVID-19, School Reopening, and Student Wellness. Journal of School Health, 91(5), 376-383.

11. Pendong, R. J., Himpong, M. D., \& Lotulung, L. J. (2021). SIKAP PEMUDA TENTANG PROTOKOL KESEHATAN COVID-19 DI DESA LOMPAD KECAMATAN RANOYAPO KABUPATEN MINAHASA SELATAN. ACTA DIURNA KOMUNIKASI, 3(2).

12. Sabiq, A. F. (2020). Persepsi Orang Tua Siswa tentang Pembelajaran Tatap Muka pada Era New Normal Pandemi Covid-19. Journal of Islamic Education Research, 1(3), 179-189.

13. Sari, R. K. (2021). Identifikasi penyebab ketidakpatuhan warga terhadap penerapan protokol kesehatan 3M di masa pandemi Covid-19 (studi kasus pelanggar protokol kesehatan 3M di Ciracas Jakarta Timur). Jurnal Akrab Juara, 6(1), 84-94.

14. Saputro, A. A., Saputra, Y. D., \& Prasetyo, G. B. (2020). Analisis Dampak Covid-19 Terhadap Kesadaran Masyarakat Dalam Penerapan Protokol Kesehatan. Jurnal Porkes, 3(2), 81-92.

15. Umara, Y. (2020). Analisis Peran Pemerintah Daerah Menyangkut Penyelenggaraan Pembelajaran Tatap Muka. Al-Irsyad: Jurnal Pendidikan dan Konseling, 10(2). 